\title{
Identificação de Cepas Termofílicas de Campylobacter spp. por Provas Fenotípicas Convencionais, API Campy® e Sistema REP-PCR Semi Automatizado
}

Thalyta Marina Benetti (III), Wanda Moscalewski Abrahão (II,I), Tereza Cristina Rocha Moreira Oliveira (III)

(I) UFPR - Universidade Federal de Paraná ( Av. Lothário Meissner, 632, CEP: 80210-170, Jardim Botânico, Curitiba, PR), (II) LACEN-PR - Laboratório Central do Estado do Paraná (Rua Amintas de Barros, 816 Bairro Alto da XV - Curitiba/PR CEP: 80.060-200)

\section{Resumo}

A diferenciação entre as espécies de Campylobacter spp. é necessária para vigilância epidemiológica e na avaliação de risco, porque C. jejuni é a espécie mais associada à campilobacteriose humana. Problemas na identificação das espécies de Campylobacter estão relacionados à incapacidade desse gênero de metabolizar carboidratos, de serem bioquimicamente pouco ativos e da falta de padronização dos testes utilizados nos laboratórios, o que dificulta a comparação de dados. No presente trabalho foram avaliados dois métodos fenotípicos (sistema API Campy® (Biomerieux) e provas fenotípicas convencionais) e um método genotípico (sistema REP-PCR, Diversilab ${ }^{\circledR}$, Biomerieux) para a identificação de isolados de Campylobacter spp. de amostras clínicas e de alimentos. Um total de 43 isolados de Campylobacter spp., proveniente de carcaças de frango resfriadas e de fezes humanas, foi estudado neste trabalho. Os isolados pertencem a coleção de culturas do Laboratório Central do Estado do Paraná (LACEN-PR). As provas fenotípicas convencionais utilizadas foram catalase, oxidase, hidrólise de hipurato, hidrólise do indoxil acetato, e avaliação da sensibilidade ao ácido nalidíxico e à cefalotina (Oxoid, Inglaterra). A identificação empregando o sistema API Campy® (Biomerieux) e técnica semi-automatizada Diversilab® (Biomerieux) foi realizada de acordo com as instruções do

\footnotetext{
Referência:

Thalyta Marina Benetti, Wanda Moscalewski Abrahão, Tereza Cristina Rocha Moreira Oliveira. Identificação de Cepas Termofílicas de Campylobacter Spp. por Provas Fenotípicas Convencionais, Api Campy® e Sistema Rep-Pcr Semi Automatizado. In: Anais do 12 Congresso Latinoamericano de Microbiologia e Higiene de Alimentos - MICROAL 2014 [= Blucher Food Science Proceedings, num.1, vol.1]. São Paulo: Editora Blucher, 2014.

DOI 10.5151/foodsci-microal-254
} 
fabricante. A percentagem de concordância entre os três métodos avaliados foi de $83,7 \%$ com discrepância na identificação em sete isolados. Neste estudo, apesar de todas as dificuldades já relatadas quando do uso das provas fenotípicas tradicionais, estas mostraram o melhor desempenho dentre as técnicas avaliadas, a maioria dos isolados foi $(93,0 \%)$ adequadamente identificada (40/43) por esta técnica. Não foi possível a identificação das espécies hipurato negativas, mesmo após a realização do sequenciamento. Os resultados do presente trabalho sugerem que o uso das provas fenotípicas convencionais para a identificação das espécies de Campylobacter termofílicas é adequado para as espécies hipurato positivas.

Palavras-Chave: Campylobacter spp., identificação, Diversilab, sistema API CAMPY®, provas fenotípicas

Agência de Fomento: 